J O U R A L O F

French and Francophone Philosophy
REV U D D L A

philosophie française et de langue française

\title{
The Fifth Antinomy: A Reading of Torture for a Post-Kantian Moral Philosophy
}

Roy Ben-Shai

Journal of French and Francophone Philosophy - Revue de la philosophie française et de langue française, Vol XXIV, No 3 (2016) 17-37.

\author{
Vol XXIV, No 3 (2016) \\ ISSN 1936-6280 (print) \\ ISSN 2155-1162 (online) \\ DOI 10.5195/ jffp. 2016.785 \\ www.jffp.org
}

\section{(c) EY-NC-ND}

This work is licensed under a Creative Commons Attribution-Noncommercial-No Derivative Works 3.0 United States License.

\section{ULIS D-Sull}

This journal is operated by the University Library System of the University of Pittsburgh as part of its D-Scribe Digital Publishing Program, and is co-sponsored by the University of Pittsburgh Press 


\title{
The Fifth Antinomy
}

A Reading of Torture for a Post-Kantian Moral Philosophy

\author{
Roy Ben-Shai \\ Stony Brook University
}

For Enlightenment of this kind, all that is needed is freedom.

- Immanuel Kant ${ }^{1}$

\section{Introduction}

Where is it decreed that enlightenment must be free of emotion? To me, the opposite seems to be true. Enlightenment can properly fulfill its task only if it sets to work with passion. ${ }^{2}$

This statement, which concludes the preface to the 1977 reissue of At the Mind's Limits, conveys the philosophical ambition of the book: to advance the enlightenment project, while revising the way we understand this project. The idea, rejected here by Améry, that the enlightenment "must be free of emotion" owes most to its foremost proponent, Immanuel Kant. This paper picks up on this implicit allusion to Kant, and elaborates on Améry's revision of the enlightenment by making the confrontation between them explicit.

For Kant, enlightenment meant a turning point, individual and collective, from immaturity to maturity: from intellectual tutelage and dogmatism to intellectual autonomy and the courage to know and think for oneself. ${ }^{3}$ By "tutelage" Kant did not only mean political oppression or external control, but first and foremost the "self-imposed" passivity of those who, while fully endowed with rational faculties, let their reasoning be governed by passions and emotions, by narrow self-interest, and by force of habit and external decree. Enlightenment, on his view, inverts this order, rendering reason sovereign and turning each individual and society at large into the agents of their existence.

Améry's emphasis on passion is not a mere reversal or rejection of this process of maturation, and to understand it requires to rethink what passion 
means. The original meaning of passion, like that of passivity (both derive from the Latin root pati-) is being-acted-upon and being-affected-by. In other words, passion is having something done to you or happen to you, as opposed to action, which is what you make happen. I will argue that torture, whose analysis is the focus of the second essay of At the Mind's Limits, is a paradigmatic case of passion in this original sense. ${ }^{4}$

The subject of passion-the one acted upon-is a patient or victim. Kant's critical philosophy allows no room for this modality of subjectivity, as it hinges on a fundamental opposition between an agent (the subject of practical thinking) and a spectator (the subject of theoretical thinking), and between transcendental subjectivity and empirical subjectivity. Passivity, in turn, is seen as a deficiency, a mere case of ignorance or immaturity. To work with passion, I will argue, requires seeing passivity as a categorically different modality of experience and subjectivity, and to think towards victimhood instead of thinking it away.

Thinking towards victimhood is also thinking towards the limits of the mind (An den Grenzen des Geistes)-a dimension in which the mind is not the mover but moved. Thinking towards its own limits advances the critical selfawareness of reason and is therefore vital to the enlightehment project. Yet this mode of thinking is precluded by Kant due to his efforts to fortify reason within its proper ("pure") domain.

This paper is divided into two main parts. The first analyzes Kant's Antinomy of Pure Reason, in particular the third antinomy (of freedom), in which he articulates what I call his 'dual standpoint theory', categorically distinguishing between the practical and the theoretical tasks of reason and between the two modalities of subjectivity-the "empirical" and the "intelligible." With this Kantian framework as a background, the second part reconstructs Améry's work, especially in his essay on torture, as proposing a new or modified antinomy, which I call "the fifth antinomy," and from it, a third mode of thinking that is neither theoretical nor practical. I call this third mode of thinking "pathological," while distinguishing it from the kind of thinking that Kant labeled as such. The conclusion returns to address the question of what enlightenment means if it "sets to work with passion."

\section{The Third Antinomy in Kant and Dual-Standpoint Theory}

a) What is an antinomy?

The "Antinomy of Pure Reason" as Kant names it in the Critique of Pure Reason is a structural feature of reason that is responsible for some of the most pervasive metaphysical disputes in the history of philosophy. These disputes all revolve around "cosmological ideas," namely, assumptions or claims about the world or about nature as a whole. In disputes of this sort, 
Kant observes, one of the sides-the "thesis"-is dogmatist, and the other-the "antithesis"-is empiricist. The dogmatist advances absolute and a-priori truth-claims (e.g., that the world has a beginning in time, or is created and governed by God). The empiricist categorically rejects the validity of these claims because they are not empirically verifiable. As is the case with all disputes, what motivates this one is the conviction that one side must be wrong and the other right, which means that the philosopher must choose sides and be either a dogmatist or an empiricist. Kant aims to "solve" the antinomy by showing that there is no real choice to be made and no ground for dispute.

His overarching claim is that the root of the antinomy is a duality within reason between two different faculties: pure Reason and the Understanding. The proper field of the Understanding is appearances (sensory experience), which it arranges in time and space according to its concepts with the help of the Imagination. The proper domain of Pure Reason, by contrast, is apriori, transcendental ideas that are essentially independent of the world of appearances. The semblance of a dispute between a thesis and an antithesis results from a failure to adequately distinguish between these faculties and their respective domains, and more generally speaking, from the failure to distinguish between appearances and things-in-themselves. Consequently, the faculties infringe on each other's jurisdiction. Thus, for example, when we envision a "personal" God as located in some place or time, in or beyond the world, we are making an appearance out of a pure idea (of an absolute/necessary being); and when we claim that God (an absolute/necessary being) does not exist, because it cannot possibly appear, we are in effect reducing an idea to empirical presence. The ultimate task of a "critique" of reason is to clarify the structure of reason-both in its overarching unity as a complex, and in its inner division into faculties and jurisdictions. Such clarification allows us to prevent transgression between categorically different modes of thought, but also to harmonize their operation in the common interest of the whole, namely, self-governance.

\section{b) The third antinomy and its solution}

With his known penchant for tetralogical constructions, Kant enumerates four antinomies, or four manifestations of the antinomic structure. The third of these, "the antinomy of freedom," is responsible for the age-old dispute between advocates of predetermination and advocates of free will. As Kant dubs it, the antithesis of this antinomy argues that there "is no freedom [and] everything in the world takes place in accordance with the laws of nature," while the thesis insists that "there is also another causality, that of freedom." 5

When dubbing the thesis of the antinomy, Kant resorts to the firstperson voice, a literary gesture more often associated with a writer like 
Descartes, and gives the following example: "for instance, I at this moment arise from my chair, in complete freedom, without being necessarily determined thereto by the influence of natural causes." 6 But of course, the claim that this example demonstrates freedom is precisely what stands in dispute.

To clarify the empiricist standpoint on the matter, let us name the physiological (chemical, neurological, muscular) processes that occur in the person's body as ' $x$ ', ' $y$ ', and ' $z$ '. The empiricist states that if $x, y$, and $z$ happen, then the body in which they occur will necessarily get up from the chair. Moreover, if they do not happen, it will necessarily remain seated. There is, therefore, a chain of natural causes that provides sufficient explanation for the movement and leaves neither room nor need for postulating something like choice. Kant's response in defense of the thesis is that the "causality of our will... independently of those natural causes, and even contrary to their force and influence... [can] begin a series of events entirely of itself." 7 Apparently, this means that the reason for which $x, y$, and $z$ happened in the first place is the choice of free will. But the problem is precisely that no such "beginning" manifests itself in sensory experience. To answer the question of why $x, y, z$ happened in the first place, the scientist will go on pointing out antecedent occurrences $(u, v, w \ldots$ and so back indefinitely).

The solution Kant proposes for this conundrum is transcendental. Understood transcendentally, "beginning a new series" does not simply mean beginning a particular series but modifying the entire series of events. To borrow a phrase from Wittgenstein: with the action of the will, the world "waxes or wanes as a whole." 8 This means that the phrase "new series" refers not only to what comes after a particular action takes place but also to what comes before it. It is as if a free action changed at once the past, the present, and the future.

The transcendental solution requires to leave the grounds of both the empiricist and the dogmatist mindset and concede to the opening gesture of the Critique of Pure Reason, where Kant claims that time is a form of intuition and not a thing in itself. On this view, the "past" and its contents are not a pre-given, as we normally tend to assume, but are the product of a regressive synthesis of information. This regressive synthesis is what empirical science does whenever it explicates particular appearances: it begins from a given event and traces it back to antecedent causes. For that, it does not simply discover causal connections but actively establishes them. Science is therefore something we do in accordance with the laws of nature.

The scientific postulate that every event must have a natural cause according to the law of nature is therefore not an axiom (a truth about nature "itself") but a "regulative principle." It determines how we, in our capacity as scientists, ought to think. This regulative principle, as Kant puts it, "is thus 
properly only a rule, prescribing a regress in the series of the conditions of given appearances, and forbidding it to bring the regress to a close by treating anything at which it may arrive as absolutely unconditioned." 9

What makes such indefinite regress necessarily possible is the structure of human experience, in which factual and sensory data are always already, spontaneously, informed and arranged by the Imagination in accordance with the rules of the Understanding. But these rules only apply to appearances. The laws of nature are essentially the laws of the Understanding and the Imagination and they only govern and determine the relationship between one appearance and another, given that they appear. The reason for which scientific inquiry will never find evidence of freedom is not that it does not exist but that it does not operate in time: it is not an appearance but a cause underlying appearances and their synthesis. Because the jurisdiction of science is only the field of appearance, it is unqualified, and forbidden, to pass judgment on whether freedom exists or not. As soon as it tries to answer this question, it violates its own rule.

The dogmatic stance is similarly overreaching insofar as it attempts to "point" to the occurrence of freedom within the field of appearances ("I at this moment arise from my chair...."). What is common to dogmatism and empiricism is therefore the conflation of the transcendental and the empirical. Both treat freedom, which is a transcendental idea, as an empirical phenomenon - the one denying and the other affirming it as such. In truth, just as natural causality is not a given fact but a rule for the guidance of scientific thinking, so too freedom is not a given fact but a rule for the orientation of practical thinking.

Finally, the reason for which there is no concrete clash between the postulation of freedom and that of natural causality is that, unlike a miracle, whose effects would visibly violate the laws of nature, the causality of the will has simply nothing to do with these laws. It only determines whether and why certain things ought to happen, but not the way by which they appear and the laws that govern their appearance when they do.

\section{c) The dual standpoint theory}

If we can keep these conclusions steadily in view the self-conflict of reason will be entirely at an end. For not only will this critical solution destroy the illusion which set reason at variance with itself, but it will replace it by a teaching which, in correcting the misinterpretation that has been the sole source of the conflict, brings reason into agreement with itself. ${ }^{10}$

This solution brings the essence of Kant's "critical turn" into relief, namely, the claim that the manner by which we think determines in large part what world we see and live in. There is no real dispute between theoretical and 
practical thinking because both are valid and necessary. They are valid, however, not in adequately describing the world, which would imply that the world is independent of our description of it, but in adequately determining $a$ way of looking at, and thinking about, the world. This point is not merely theoretical. Arguably, there is a difference between the conduct of a person who believes herself to be free, and therefore accountable and responsible for her actions, and one who believes all her actions are determined by chance or law. Similarly, there is a difference between the way nature appears to a person who believes that everything that happens must be provided scientific explanation, and the way it appears to a person who assumes the workings of metaphysical, theological, mystical or mythological forces.

Instead of a dispute between an empiricist and a dogmatist stance, we now have a distinction between two different intellectual registers and domains of reflections: science, or theoretical reasoning, and morality, or practical reasoning-the former is grounded in and committed to natural law, and the latter is grounded in and committed to the idea of freedom; the former works strictly in time, the latter through strictly a-priori and universal principles. Kant describes them alternately as different "standpoints" or "points of view." This dual-standpoint theory means that one can at each point adopt or practice one or the other, but ought never to conflate the two.

The importance of this theory for the possibility of moral reflection, according to Kant, is that, while it respects natural causality and the integrity of natural science, it also opens up an entire dimension-as it were, underneath the unchangeable course of time-in which nothing is necessary or simply "the case," and everything is subject to judgment. The existence of this dimension allows, and demands of us, to raise questions such as: Why did this happen? Was it the right thing to do? It also makes it impossible for us to ever be content with the simple factual observation that some things happen and cannot be undone.

The overall interest of reason, which for Kant is attaining selfgovernance, includes both the theoretical interest in advancing knowledge of "what is, what has been, or what will be,"11 and the practical interest in the good-the way things ought to be. Science allows us to understand history, and morality allows us to judge it. Far from needing to usurp or disqualify each other, it is in their common interest to keep their respective domains separate, and alive.

\section{d) The dual nature of the human being}

[Seen in] this way, freedom and nature, in the full sense of these terms, can exist together, without any conflict, in the same actions, 
according as the actions are referred to their intelligible or to their sensible cause. ${ }^{12}$

Parallel to the distinction between the two standpoints, Kant draws a distinction between the "empirical" and "intelligible" character of a person, to which each of them "refers." Taken in its theoretical context, the "empirical character" is a synthesis of the sensory appearances of a person in time and space (say, the body and its history). In the practical context, it refers to the synthesis of "sensuous impulses"-the manifold ways by which the person is conditioned to act. The "intelligible character," on the other hand, is the person's reasoning: not the synthesis of sensations but their synthesizing. Due to its transcendental stature, such reasoning is entirely "unaffected by... sensible influences, and [is] not liable to alteration [by them]." 13 Reason is therefore categorically free, and provides an entirely different ground for the determination of the will.

Freedom, Kant explains, "is the will's [Willkür] independence of coercion [by] sensuous impulses." 14

No matter how many sensuous impulses may impel me to will, they can never give rise to the "ought," but only to a willing which, while very far from being necessary, is always conditioned; and the "ought" pronounced by reason confronts such willing with a limit and an end-nay more, forbids and authorizes it. ${ }^{15}$

In its moral function, practical reason "frames for itself with perfect spontaneity an order of its own according to ideas to which it adapts the empirical conditions." 16 This law, the moral law, dictates that we must always guide our thinking and conduct according to strictly universalizable standards. One of the most famous, and contentful, of Kant's formulations of the moral law reads: "Act in such a way that you treat humanity, whether in your own person or in the person of another, always at the same time as an end and never simply as a means." 17

The bleak side of this philosophy is in the realization that, while freedom grounds the possibility of self-governance, it also inevitably opens the possibility of evil. An evil person is not one who fails to enforce reason over sensuous impulses. Rather, she is one who willfully and methodically inverts this order, making it a rule to live by that reason must always act in the service of sensuous impulse. In such a case, reason produces an antimoral law: to act in such a way that you treat humanity in yourself or in others always as a means and never as an end. When we encounter an evil person, we do not witness the capriciousness of sensuous impulses but the consistency and deliberation of a rational mind.

Perhaps the most important and controversial message of Kant's moral philosophy is that, when we morally judge a person (or ourselves), we must neither excuse nor blame them for empirical circumstances, but only 
for the choices they make. To the extent that we consider a person rational, we cannot take the empirical circumstances of her lives and character as determining or explaining her actions, for these circumstances are subject to her own synsthesis. We must "regard reason as a cause that irrespective of all... empirical conditions could have determined, and ought to have determined, the agent to act otherwise."18

Because the causality of reason does not take place in time, but in each case modifies the entire series of conditions, we can always state that a "different intelligible character would have yielded a different empirical character." 19

\section{e) After Kant}

The problems incurred by Kant's dual-standpoint and dual-character theory, on both the theoretical and practical levels, are multiple, and have been occupying both supporters and critics from the first publication of the Critique Pure Reason to this day. My own intention is not to judge Kant's view for its problems, let alone to try and resolve them. Instead, I take his view as a given framework of thought, seeing as Améry is both profoundly influenced by it, and struggling against it. My reconstruction of Améry's argument will present him as proposing a third standpoint-different both from that of Reason and from that of the Understanding, and corresponding to it, a third dimension of personhood-different both from what Kant calls the "empirical" and from the "intelligible" character. I will call the third standpoint pathological and the third dimension passivity or victimhood. While this scheme deviates significantly from Kant's thought and agenda, it follows his footsteps in at least one important respect: in endeavoring to draw a categorical distinction, and antinomic relation, between qualitatively different dimensions of experience, and between the different registers of thought that refer to them.

\section{Améry's Fifth Antinomy and the Path of Moral Pathology}

\section{a) A singular evil}

I will begin my analysis of Améry where my analysis of Kant ended: in his notion of evil. In the Preface to At the Mind's Limits Améry writes that "there is nothing"

that provides enlightenment on the eruption of evil in Germany... this evil really is singular and irreducible in its total inner logic and its accursed rationality... For this reason, all of us are still faced with a dark riddle... And all attempts at economic explanation, all the despairing one-dimensional allusions to the fact that Germany's industrial capital, concerned about its privileges, financed Hitler, 
tell the eyewitness nothing, tell him just as little as the sophisticated speculations about the dialectics of enlightenment. ${ }^{20}$

Translated into Kantian terms the rejection of "attempts at economic explanation" is a rejection of the standpoint of the Understanding, or the empiricist attitude, whose regulative principle is to provide causal explications. Under the backing of this principle the empiricist standpoint would either bracket out or explain away whatever is "riddling" about history, for the same reason it denies free will: not because it does not exist but because "it is not of any use in explaining appearances." 21

Améry's affinity to Kant, however, extends only this far. What, according to him, resists the Understanding is not the intelligible character of the event (the rational agency behind it), the judgment of which belongs to the proper domain of pure practical reason, but a "dark riddle"-something that defies Reason just as much as it does the Understanding.

In the effort to explain the "singular and irreducible" nature of the evil of the Third Reich without dispelling the dark riddle that surrounds it, Améry interprets it as "sadistic." Opposing the common perception of sadism as a psycho-sexual disorder, he defines it as a disorder of reason. In his words: a "twisted [ver-rückte] view of the world." 22 The adjective verrückte ordinarily connotes madness, ${ }^{23}$ and this connotation is one of the main points Améry drives by equating Nazism to sadism. He elsewhere states explicitly that living in the Nazi regime resembled taking a tour through "a psychiatric clinic" 24 without any doctors or orderlies in sight. 25

What most characterizes the twisted worldview of Nazism was its destructiveness. In Auschwitz, whose operation Améry regards as exemplary of the overall logic of the Reich, "the SS was employing a logic of destruction that itself operated just as consistently as the logic of life preservation did in the outside world." 26 And in the essay on torture, endorsing Bataille's understanding of Sade's philosophy, he notes that the sadist "does not care about the continued existence of the world," but, on "the contrary: he wants to nullify this world." 27 This kind of wish cannot, however, be carried out simpliciter, since even if the sadist were able to "nullify this world" he would be nullifying himself therewith. This is why the sadistic logic epitomizes in torture. Creating enclaves of sustained destruction-death camps and torture chambers-the sadist approximates the experience of world-annihilation as much as it is humanly possible, bearing it through the destruction of his victims' world.

We saw that Kant's understanding of evil involves a reversal of the moral law, whereby, for example, one sets for oneself as a principle to always treat humanity in oneself and in others as a means and never as an end. The language of "means" and "ends," however, falls drastically short of capturing the singularity of sadism on Améry's account. Unlike the case of slavery, which arguably consists of subordinating the other's freedom to 
one's own gains, in sadistic torture-torture for torture's sake-there is no ulterior motive for the sake of which the victim can be said to be "used." "The Nazis," Améry explains,

tortured as did others, because by means of torture they wanted to obtain information important for national policy... They martyred their prisoners for definite purposes, which in each instance were exactly specified. Above all, however, they tortured because they were torturers. They placed torture in their service. But even more fervently they were its servants. ${ }^{28}$

The sadist, on this view, does indeed treat the humanity of the other as an end, except that the end is to not to elevate but to destroy it. Nazism "hated the word 'humanity' like the pious man hates sin." 29 The act of torturing humans was therefore a form of pious devotion to the task, and experience, of dehumanization, which is very different from ignoring or misrecognizing their humanity. The governing logic of the regime, Améry concludes, was the Herrschaft des Gegenmenschen, "the rule of the antiman." 30

I should note in this context that Améry's understanding of "humanity" significantly differs from Kant's. Whereas the essence of the human for Kant is spontaneity: free and rational agency, for Améry it is essentially a form of relation. The term he often uses for humanity is Mitmenschlichkeit, which literally means co-humanity, or humanity-with. The rule of the anti-man (Gegenmenschen), like the act of torture itself, retains the relational essence of humanity while perverting it from within, turning the with- (Mit-) to against- (Gegen-). Common interpretations of torture tend to downstate the fact that it is a relational, even intimate, practice par excellence. More often, they focus on the violation of the tortured person and her dignity rather than the violation of relationality, which may better account for the traumatic effects of such an experience (e.g., the difficulties of forming relations) on both parties involved.

While any practice of torture, for Améry, is anti-human in this sense, what was singular about the Third Reich was it being "the only political system of this century up to this point that had not only practiced the rule of the antiman, as had other... regimes, but had expressly established it as a principle." 31

In view of such a statement, we might be inclined to raise the question once again: does not this view of sadism fit perfectly into Kant's definition of evil as a will that makes it a principle to always obey sensuous impulses?

The truth of the matter is that, just like the opposition between "means" and "ends," the one between "sensuous impulses" and "principles" is altogether unhelpful in capturing the singularity of sadistic evil. Améry's account subverts both sides of this dualism. For one thing, in 
keeping with his view of humanity as Mitmenschlichkeit, he associates sensuous impulses with care and attachment rather than with self-interest and self-preservation. But even more importantly, he does not see the principle of torture as obeying sensuous impulses, but on the contrary, as forbidding them. "The Hitler vassal," he explains, "had to torture... in order to be great in bearing the suffering of others... so that Himmler would assure him [that] later generations would admire him for having obliterated his feelings of mercy." 32

This observation is interestingly supported by more recent studies, ${ }^{33}$ which point out that, in his lectures to his officers, Himmler routinely deployed a deontological vocabulary, pressing it upon his audience that in doing what they did (the nature of the deeds remained unspoken) they were carrying out their moral duty. The use of this kind of rhetoric suggests that Himmler's officers were by no means enjoying their job. In fact, many, if not most, were severely demoralized. What Himmler asked of them was to sacrifice their self-interest and well-being for the higher ends of posterity and the common good. It is therefore not some inbred cruelty that defines sadism for Améry, but a defiance of natural-instinct on strictly moral grounds.

Like some of Sade's own writings, this account of sadism eerily reads as an immanent perversion of Kant's logic, uncovering perhaps a deep emptiness at its heart. It suggests an openness, or indifference, in Kant's moral philosophy to a kind of evil that it cannot see or name, because it insists on portraying reason as pure and inviolable.

Among the questions looming behind this account, producing its darkly riddling effect, are: Who is the agent behind the rule of the antiman? What does this agency want? And why does she want it?

The truth of the matter is that no agency is postulated here at all. The Nazis, as Améry suggestively puts it, placed themselves in the service of their Prinzip, not the other way around. Therefore, the concept of freedom, which underlies Kant's moral philosophy and enlightenment in their entirety, is conspicuously absent from Améry's text. Torture usurps freedom as the "transcendental idea" that grounds reflection.

\section{b) A "fifth" antinomy}

In a suggestive passage already cited, Améry states that Nazi evil "issued, so to speak, through spontaneous generation [Urzeugung] from a womb that bore it as a perversion [Widernatur]." 34 The English translation of Urzeugung as "spontaneous generation" nicely underscores both the commonality with, and difference from, Kant. "Spontaneous" means stemming from its own unique origin and forming its own law. As we saw, Kant takes this to be another term for freedom, yet Améry shows us that the two are not 
synonymous. Freedom, if you will, is a species of spontaneity. The perversion of reason, or evil, is another.

Medical terminology has a name for a disease that "issues through spontaneous generation." It is called an "idiopathic" condition. Merriam Webster defines idiopathic as: "(1) arising spontaneously or from an obscure or unknown cause; (2) peculiar to the individual." Whether an idiopathic phenomenon exists or not is a moot point for both practitioners and theoreticians of medicine. But having looked at the structure of Kant's antinomy, this mootness should come as no surprise. The antithesis of the third antinomy, which denies the existence of free will, would also deny the existence of an idiopathic event, and on the same grounds: neither freedom nor an idiopathic condition can admit of empirical verification; on the contrary, empirical observation could only serve to undermine them.

If my interpretation is right, then Améry's argument presents us with a modified antinomy-a "fifth" antinomy so to speak. The thesis of this antinomy is that there is another causality but that of nature: an idiopathic causality. Yet, unlike the third antinomy, this one casts both Reason and the Understanding, both freedom and nature, to the side of the antithesis. What the thesis asserts is a perversion, and violation, of reason itself. Kant's transcendental solution to the antinomy applies here nonetheless: the event in question (the rise of Nazism in Germany) cannot be explained by recourse to antecedent conditions (e.g., economical) because it modifies the entire series, including the past, the present, and the future. ${ }^{35}$ An event that is Widernatur (literally, counter-natural), as Améry describes it, cannot be regarded as a happening in time in any ordinary sense. It is therefore futile to enter a dispute about whether his claims about Nazism are historically accurate. The postulation of a first cause-be it freedom or an idiopathic event-can neither refute nor be refuted by empirical findings. And, if it is not a dogmatic assertion, then it tells us less about what is the case and more about our mode of thinking.

To my understanding, the fifth antinomy does not deny the legitimacy of Kant's dual standpoint, namely, his convictions that: (1) freedom exists; (2) freedom and nature are mutually exclusive; and (3) practical and theoretical reasoning lead thinking along two categorically different paths. Instead, the fifth antinomy paves for us a third path of thinking that is neither theoretical nor practical. What is this thinking like? What "faculty" conducts it? And what is its point of reference?

\section{c) The turn toward the victim}

In the preface to the 1977 reissue of the book Améry writes: 
I am as little interested in the Third Reich today as I was earlier. What occupies me, and what I am qualified to speak about, is the victims of this Reich. I don't want to erect a monument for them, for to be a victim alone is not an honor. I only wanted to describe their condition-which is unchangeable. ${ }^{36}$

Given how much he has to say about the Third Reich, it might surprise us to hear that he has "little interest" in it. Yet, clarifying this disinterest, I believe, is precisely the point of of his thesis about the Reich. Pathologizing Nazism, and in effect denying both the path of freedom and the path of nature in explaining it, operates like a phenomenological epoche (suspension, or bracketing-out). By bracketing out any reasonable, causal and agentive context to the torturous regime, this thesis shifts the focus of reflection to the experience of the victims of torture, thus opening way for what Améry calls "a phenomenological description of the victim-existence [Opfer-Existenz]."37

The German phrase Wesensbeschreibung, translated here as "phenomenology", literally means "essential-description." In other words, it is a description of victimhood as such. In keeping with the phenomenological tradition, to describe victimhood as such is not to give it a dictionary definition, but to ask what it means to be a victim. In questions of this kind, the questioner must be thrown into the question-undergo the victim's experience in her own person. Améry makes it clear, however, that this is not possible. Even he, in his capacity as author, cannot properly claim or occupy the victim position. By the mere fact of writing and thinking, and especially communicating with others, one already transcends victimhood. As my analysis will suggest, it belongs to the essence of the victim-existence, as exemplified in the experience of torture, that one is completely solitary and cut-off. Nevertheless, the irony is that experiencing the impossibility of identification and communication already makes for an experiential approximation of the essence of such a state.

Here is the place to state that, in my view, a "phenomenology of the victim-existence" is more adequately termed "pathology." For Kant, "pathology" meant an a-moral mode of practical reasoning, one guided by emotion and self-interest rather than by duty. In its terminologically precise sense, however, pathology means a thinking or study (logos) that is concerned with pathos (Greek for suffering and passivity). Pathology in this sense, to recall Améry's phrase, is a thinking that "sets to work with passion." Once we take the experience of torture as our point of departure to the study of passion, we understand that it cannot be conflated with selfinterested desire. On the contrary, the subject of passion-the victim-is denied a self, separated from her "sensuous impulses" just as much as she is from her rationality and will.

A passage in the torture essay, in which Améry describes his first experience of torture in uncharacteristically graphic detail, brings the loss of 
both self and community to the fore. This experience, and the passage that describes it, are important because, as Améry puts it, they capture the moment in which "victimization" (the turn to the victim-existence) is "complete:"

In the bunker there hung from the vaulted ceiling a chain that above went into a roll. At its bottom end it bore a heavy, broadly curved iron hook. I was led to the instrument. The hook gripped into the shackle that held my hands together behind my back. Then I was raised with the chain until I hung about a meter over the floor. In such a position, or rather, when hanging this way, with your hands behind your back, for a short time you can hold at a half-oblique through muscular force... All your life is gathered in a single, limited area of the body, the shoulder joints, and it does not react; for it exhausts itself completely in the expenditure of energy. But this cannot last long, even with people who have a strong physical constitution. As for me, I had to give up rather quickly. And now there was a crackling and splintering in my shoulders that my body has not forgotten until this hour. The balls sprang from their sockets. My own body weight caused luxation; I fell into a void and now hung by my dislocated arms, which had been torn high from behind and were now twisted over my head. Torture, from Latin torquere, to twist. What visual instruction in etymology! 38

While this is not, as he stresses, the worst form of torture imaginable (in terms of degree), it does, he believes, capture the essence of torture (in terms of kind), and with it, the essence of the victim-existence. Torture, as he reminds us, originally means "twist." The victim's twisted state graphically illustrates the "twisted [ver-rückte] view of the world" of the Nazi regime. ${ }^{39}$ It also turns the word "torture" from a stock-in-trade term into a proper name; making it touch, if only proximately and briefly, the experience and reality it names, and the mind-numbing insanity of it.

The "dislocation" of the arms is symbolic in at least two important ways: (1) as loss of agency and hold over the situation; (2) as the move out of location and localization; a thrust unto the limits of time and space, and with them, out of the possibility of sharing, depicting, objectifying, relating, and indeed, experiencing in the Kantian sense of the term. This dislocation is, therefore, like a "fall into void."

Falling into void is losing ground. Ground is both reason (or cause) and subjectivity. The victim becomes the happening, with no mediation or distance. There is no more "object" or intentionality to the experience, no relation or distance between self and other, inside and outside, no more energy or desire but only condensed pain. The limits of the body are broken, 
as it is turned against itself, and destroyed as an organic, self-moving and self-preserving unit.

"Whoever is overcome by pain through torture," Améry writes, "experiences his body as never before. In self-negation [Selbstnegation], his flesh becomes total reality." 40 "Self-negation" is not a negation of the self (by itself) but a paradoxically experienced loss of self, along with the categorical distinction between self and other and self and reality. Both Heidegger and Wittgenstein made the claim that the essence of death is the impossibility (limit) of experience. Améry claims, however, that torture "blots out the contradiction of death and allows us to experience it personally." 41

The text itself falls here into a void, and meaninglessness. The most it can do is mark a limit to what can be said or shown. Yet it nonetheless endeavors to pull us, readers, nearer to the edge of this void, and thus farther from ourselves and our present state as readers and thinkers. Suggestively, Améry notes that, while "no road that can be traveled by logic leads us to death... perhaps the thought is permissible that through pain $a$ path of feeling and premonition can be paved to it for us." 42 The telos of this path of feeling, I believe, is not torture or death per se, any more than it is sadism or the Third Reich. The aim is rather to develop and cultivate our capacity to approximate the limits of ourselves and of the world, and to empathetically navigate toward the experience of victims. The capacity to do so does not fall under the jurisdictions of the Understanding, Reason, or the Imagination, and it is important-critical, in the precise sense of the wordthat we disallow them from taking over the operation of thought.

Whereas what Kant calls the "empirical character" is in some sense always an other (even when it is mine), since its existence presupposes a removed spectator, and what he calls the "intelligible character" is always essentially a self, a cogito (even when it is another's), the "victim-existence" is never properly self or other, since victimhood destroys the distance and relation between self and other. We should therefore realize that approximating the void of the victim-existence is never simply a matter of approximating the experience of another person (that which is "beyond" the limit, so to speak), but of approximating the limits of Geist as such.

Thus located at the limits of Geist, of time and space, victimhood requires a quasi-transcendental status, on a par with the agent and the spectator, yet different from both. Setting this third mode of being as a horizon and standard marks out a different, pathological, path of thinkingfeeling that is neither practical nor theoretical. This path lacks the selfgrounding and certainty of the other two and denies, rather than grants, the self-governance they claim. Yet by turning away from it, or denying it, reason remains partially blind to its own nature and to its essential limitations. It therefore fails to live up the "courage to know" exhalted by Kant. 


\section{d) Impractical morality}

Under the auspices of pure practical reason, if we deny free agency to the Nazis, we effectively absolve them of their accountability and deprive the event of all moral significance. The experience of victims, conversely, is, for practical reason, derivative at best.

Pathological thinking as I present it here is impractical, which is not the same as "non-practical." It inverts the point of view of practical reasoning and its order of priorities. For it, as we saw in the case of Améry, what endows an event with significance is the presence of a victim and suffering. By contrast, the question of whether there is or is not free agency behind the victim experience is derivative at best.

Whereas practical reasoning, following "a rule of its own" as Kant puts it, always postulates the existence of free agents and intelligible causes, and theoretical reasoning always produces causal explications, pathology always seeks out the victim. And, just like there is no real conflict between practical and theoretical thinking, so too there should be no real conflict between either of them and pathological thinking. Given a transcendental perspective, these standpoints are reconciled as antinomic rules for reflection. But the point on which a dispute between practical and pathological thinking is perhaps inevitable is the meaning of morality: to which of the two does the adjective "moral" properly belong?

There is a whole category of acts that are of supreme import from the point of view of practical reason but fall completely out of the spectrum of pathology, and vice versa. A certain case of theft or dishonesty, for example, may be of moral significance to practical reason but not to pathological thinking. The experience of terminal illness, in which there is no hostile agent (other than nature itself perhaps) but only a suffering patient, may not in itself be a moral issue, or any issue at all, for practical philosophy, but for pathology it is morally charged. In fact, the moral significance of one and the same act or experience would be located in completely different places by each of these standpoints.

This dispute is far more difficult to resolve for it is a matter of moral sensibility. As we saw in Kant, the very notion of "moral sensibility" may be oxymoronic since pure practical reasoning establishes the moral domain as categorically unaffected. Being unmoved is its greatest source of pride and what it most respects about humanity as such. This Stoic ideal of moral apathy, however, suggests a troublesome affinity, or at least lack of sufficiently strong opposition, between this kind of thinking and "the rule of the antiman." 


\section{Conclusion}

If my reconstruction is valid, then Améry's argument is just as much aimed at intellectuals as it is at the perpetrators of this particular historical event. One thing in common to Nazism and agency-centered philosophies like Kant's is their hubris. The Nazis hated humanity because it involves passivity. Kant loved humanity because he thought that, at its best or emblematic condition, it doesn't. Both were averse to the same thing.

The Nazis longed to purify themselves not only of Jews, but of the Roma, the Poles, the old, the mentally and the fatally ill... in short, of all things they considered pathetic, abject, unbeautiful, and unhealthy. To counter Nazism, not only as a historical occurrence, but as an essence, is to muster the courage to face the pathetic and even inhuman aspects of the human condition itself. Améry's refusal to "bear" his torture with equanimity, in the way Himmler expected his torturers to bear it, and his refusal to survive it as a human being or to fully regain his agency and social dignity in its aftermath, is at least in part a matter of defending passivity as such, in all its indignity.

To philosophically apply the courage to be passive, or to linger with passivity, is to reach towards limits where the mind is humbled and impoverished. Cultivating this movement of thought toward the limits of reason became Améry's intellectual mission. In one of his last books, on suicide, he claimed that, "under certain impossible conditions it is necessary to think 'toward' things that are... unthinkable." 43 "We are already," he wrote there, "on our way, not away from persons annihilating themselves, but toward them." 44 The "unthinkable" can be the condition of a suicidally depressed person, a torture victim, a Jew in Nazi Germany, or any condition that is fundamentally different from that of the thinker, and difficult to relate to and communicate with. Améry contrasted this "thinking-toward the unthinkable" to "the pumped up common sense that cannot see beyond its own interests." 45

The voices of victims, and other outcasts, become important not only because of what they had undergone, but because, or insofar, as their testimonies resist appropriation and communication, as if they spoke to us from across an insurmountable limit, or the other side of a fence. The move from grounding morality in autonomous agency to grounding it in such liminal experiences of dispossession (neither self nor other) implies a paradigm shift from a will to power and self-governance to acknowledgment of the violability and inherent relationality of the human condition. Ironically, although at the point of limit we are most estranged from others, and from ourselves, it is also at this point that we are most exposed to, and are irreducibly with, one another. 
Finally, since victimhood, however transcendental in stature, is something that happens, focusing on it necessarily grounds reflection in concrete events. This distinguishes the pathological mode of thinking from the kind grounded in a priori universal laws. Nevertheless, as we saw, the "concrete event," insofar as it becomes the ground and horizon for phenomenological reflection, is not reducible to an empirical or historiographic fact. What links these elements: the concrete event, the victim-existence, and the mind's limits, is passion, as a point of reference that categorically differs from both appearances (the empirical) and wills (the intelligible).

When seen in this way, passion is no longer regarded as obtrusive to the process of maturation, let alone as what this process needs to overcome, but as a necessary aspect of it. After all, I suspect many would agree with me that overestimating the extent of one's independence, intelligence, and powers is more a mark of adolescence than of maturity. Perhaps they may also concede that it sometimes takes a blow-a traumatizing and humbling encounter with reality-to help one grow out of this adolescent hubris and profoundly rethink one's identity, relation to others, and place in the world.

I will conclude the paper with a passage from Améry's preface, in which he proposes his own answer to the question, "what is enlightenment?':

[E]nlightenment... as I understand it... embraces [beyond logical deduction and empirical verification] the will and the ability to speculate phenomenologically, to empathize, to approach the limits of reason. Only when we fulfill the law of the enlightenment and at the same time transcend it do we reach intellectual realms in which ratio does not lead to shallow rationalism. This is why I always proceed from the concrete event, but never become lost in it; rather I always take it as an occasion for reflections that extend beyond reasoning and the pleasure in logical argument to areas of thought that lie in an uncertain twilight and will remain therein, no matter how much I strive to attain the clarity necessary in order to lend them contour. However-and in this I must persist-enlightenment is not the same as clarification [Aufklärung is nicht gleich Abklärung]. I had no clarity when I was writing this little book, I do not have it today, and I hope that I never will...

Emotions? For all I care, yes. Where is it decreed that enlightenment must be free of emotion? To me the opposite seems to be true. Enlightenment can properly fulfill its task only if its sets to work with passion. 46 
1 Immanuel Kant, "An Answer to the Question: 'What is Enlightenment?'" In: Political Writings. Edited by H.S. Reiss (Cambridge: Cambridge University Press, 1991), p. 55

2 J ean Améry. At the Mind's Limits. Translated by S. Rosenfeld and S.P. Rosenfeld (Bloomington: Indiana University Press, 1980), p. xi. From here on cited as "AML, page number."

${ }^{3}$ Kant 1991, 54.

${ }^{4}$ We can still recognize this sense in the familiar phrase, "the passion of Christ," which refers to the torture and suffering of Christ, not to his enthusiasm or commitment as the current use of passion would suggest.

5 Immanuel Kant, Critique of Pure Reason. Translated by N.C. Smith (New York: Palgrave MacMillan, 2003), A444-445/B472-473. From here on cited as "CPR, page number." The pagination follows the standard A and B German editions.

${ }^{6}$ CPR, A450/ B478.

${ }^{7}$ CPR, A534/ B562.

${ }^{8}$ Ludwig Wittgenstein, Tractatus Logico-Philosophicus (New York: Routledge, 2001), p. 87.

${ }^{9}$ CPR, A508-5099/ B536-537, my italics.

${ }^{10}$ CPR, A516/ B544.

${ }^{11}$ CPR, A547/ B575, my italics.

12 CPR, A541/ B569, my italics.

${ }^{13}$ CPR, A555/ B583.

${ }^{14}$ CPR, A534/ B562.

${ }^{15}$ CPR, A547-548/ B575-576.

${ }^{16}$ CPR, A548/ B576, my italics.

17 Immanuel Kant, Grounding for the Metaphysics of Morals (Indianapolis: Hackett Publishing Company, 1993), p. 36.

${ }^{18}$ CPR, A555/ B583, my italics.

${ }^{19}$ CPR, A548/ B576.

${ }^{20} \mathrm{AML}$, viii.

${ }^{21}$ CPR, A562/ B590, my italics.

22 J ean Améry, J enseits von Schuld und Sühne. In J ean Améry, Werke, Vol. II. Edited by G. Scheit (Stuttgart: Klett-Cotta, 2002 [1966]), p. 176 (my translation and italics).

23 In the English edition the translation reads "dis-ordered" rather than "twisted." It also omits the clause that precedes this phrase in the original-"im eigentlichen Wortverstande" ("in the proper sense of the word"). I suppose the clause was omitted because the English term "dis-ordered" 
fails to justify it (what is the "proper" sense of disordered, and how does it differ from its ordinary sense?). In German, however, while ver-rückte ordinarily means "crazy," its precise terminological sense suggests something like "being turned around (ver-) the back (Rücken)." I believe that the word "twisted" best captures this dual connotation. As I will show later on, it directly relates to Améry phenomenological description of torture.

${ }^{24} \mathrm{AML}, 96$.

25 This image is most likely borrowed from, and meant to invoke association to, Heinrich Heine. [Heinrich Heiner. On the History of Religion and Philosophy in Germany (Cambridge: Cambridge University Press, 2007), pp. 13, 85]. The association to Heine may suggest that Améry endorses his deeply critical, and ominous, analysis of German history, and perhaps Heiner's general view, reminiscent of Nietzsche's, that philosophical styles and systems stem from deeper religious and psychopathological roots unique to the peoples and cultures in which they develop. Elsewhere, Améry notes in this vein that "antisemitism has a very deeply anchored collective-psychological infrastructure which in the final analysis can probably be traced back to repressed religious sentiments and resentments." (AML, $\mathrm{x}$ )

${ }^{26} \mathrm{AML}, 10$

${ }^{27} \mathrm{AML}, 35$.

${ }^{28} \mathrm{AML}, 31$.

$29 \mathrm{lbid}$.

${ }^{30}$ Améry 2002, 71.

31 AML, 31, my italics. Looking at the conditions prevailing in Nazi concentration camps helps support the claim that there was nothing instrumental about their operation, and that their ultimate logic was destruction rather than life preservation. As Hannah Arendt and J onathan Littell, among others, have shown, while the massive deportation and internment of J ews and other populations could have been an enormous source of free labor, conducive to the war effort, it was-to the frustration of the more pragmatic factions in the regime, including industrialists and army generals-woefully wasteful, mostly due to the malnutrition and constant abuse of the inmates, and consequently, the high rates of mortality and substitution. The thoroughly regimented maltreatment of the prisoners was not the result of oversight but a commitment to dehumanization. Like Améry, both Arendt and Littell also point out to the ultimately self-destructive (masochistic?) nature of this sadistic logic. Cf. Hannah Arendt, The Origins of Totalitarianism (San Diego: Harvest, 1968), and Eichmann in J erusalem (New York: Penguin Books, 1994), and Jonathan Littell, The Kindly Ones (New York: HarperCollins Publishers, 2009).

${ }^{32} \mathrm{AML}, 30$, my italics.

${ }^{33}$ E. g., André Mineau, “Himmler's Ethics of Duty.” In The European Legacy 12 (1), 2007, 55-73.

${ }^{34}$ AML, viii; Améry 2002, 14.

${ }^{35}$ While I will not elaborate on this in the context of this paper, one of the central claims of AML is Améry's demand that the German people should collectively work to "turn time around," and make "irreversible processes... reversible." (AML, 77) At one point he also supports Magnus Erzensberg's claim that "Auschwitz is Germany's past, present and future." (AML, 78, my italics) The only way to make sense of these claims, which to ordinary understanding are counter- 
intuitive, is to acknowledge the transcendental level in which Améry's argument moves, and that, like Kant, he does not think of objective time as a "thing in itself."

${ }^{36}$ AML, viii-ix.

${ }^{37}$ AML, xiii, Améry 2002, 21, translation modified.

${ }^{38}$ AML, 32-33.

${ }^{39}$ See endnote 5 above.

${ }^{40}$ AML, 33; Améry 2002, 75.

${ }^{41} \mathrm{AML}, 34$.

$42 \mathrm{lbid}$

${ }^{43}$ J ean Améry, On Suicide (Bloomington: Indiana University Press, 1999), 28.

${ }^{44}$ Améry 1999, 4.

${ }^{45}$ Améry 1999, 5.

${ }^{46} \mathrm{AML}, \mathrm{xi}$. 